Case Reports
in Dermatology
Case Rep Dermatol 2021;13:18-22

DOI: $10.1159 / 000511494$

Published online: January 25, 2021 (c) 2021 The Author(s)

Published by S. Karger AG, Basel www.karger.com/cde

This article is licensed under the Creative Commons Attribution-NonCommercial 4.0 International License (CC BY-NC) (http://www.karger.com/Services/OpenAccessLicense). Usage and distribution for commercial purposes requires written permission.

\title{
A Case of Pruritic Urticarial Papules and Plaques of Pregnancy: Pathophysiology and Serum Cytokine Profile
}

\author{
Mai Ishikawa-Nishimura Makoto Kondo Yoshiaki Matsushima \\ Koji Habe Keiichi Yamanaka \\ Department of Dermatology, Mie University Graduate School of Medicine, Tsu, Japan
}

\section{Keywords}

Target lesion - Pruritic urticarial papules and plaques of pregnancy · Th2 • Innate immunity . IL-9

\begin{abstract}
We report a case of pruritic urticarial papules and plaques of pregnancy (PUPPP) starting with target lesions on both forearms at the end of second pregnancy. The patient's target lesions became generalized itchy edematous eczema lesions especially on her abdomen extended by pregnancy, which immediately disappeared postpartum. The mechanism PUPPP has not been elucidated so far; however, the typical target lesion was the initial phenotype in the current case. To approach the pathophysiology of PUPPP, we examined the cytokine profile in the patient's serum before and after delivery. The upregulated Th2 cytokine profile including IL-9 and IL-33, and the reaction against skin-resident bacteria and fungus might be involved in PUPPP.

(C) 2021 The Author(s)

Published by S. Karger AG, Basel
\end{abstract}

\begin{tabular}{ll}
\hline & Keiichi Yamanaka \\
& Department of Dermatology \\
& Mie University Graduate School of Medicine \\
& $2-174$ Edobashi, Tsu, Mie 514-8507 (Japan) \\
yamake@clin.medic.mie-u.ac.jp
\end{tabular}




\section{Case Reports in Dermatology}

Case Rep Dermatol 2021;13:18-22

DOI: 10.1159/000511494

(c) 2021 The Author(s). Published by S. Karger AG, Basel www.karger.com/cde

Ishikawa-Nishimura et al.: Pruritic Urticarial Papules and Plaques of Pregnancy and Cytokine Profile

\section{Introduction}

Pruritic urticarial papules and plaques of pregnancy (PUPPP) is a pruritic urticaria-like erythema with red papules that occur mainly on the abdomen of pregnant women in the late stage of first pregnancy [1]. The frequency of occurrence is 1/200 [2], and the response to topical steroids and oral antihistamines is relatively good; however, the pathophysiology of PUPPP has not been elucidated so far [3]. We here performed an immunological approach including allergic reaction against endogenous and external factors. We also examined the cytokine profile in the patient's serum before and after delivery.

\section{Case Presentation}

A 28-year-old woman who had a history of normal delivery noticed the target lesions on both forearms at 38 weeks and 5 days of the second pregnancy. Three days after the occurrence of erythema, she visited the antenatal clinic and was administered $100 \mathrm{mg}$ of hydrocortisone sodium phosphate for 2 days, but the erythema with strong pruritus expanded all over her body. She consulted our department 7 days after the appearance of erythema. Her body temperature was $37.6^{\circ} \mathrm{C}$, and an edematous eczema was noticed on her abdomen mainly around the stretch marks (Fig. 1a). Also erythema-like target lesions formed and scattered on the extremities (Fig. 1b), but mucosa was not involved. She had no prior infection, medical history, oral medication, or allergic history. Laboratory data was as follows: CRP, $0.38 \mathrm{mg} / \mathrm{dL}$; WBC, $13.46 \times 10^{3} / \mu \mathrm{L}$; band cells, $0.5 \%$; segmented cells, $73.5 \%$; monocytes, $2.5 \%$; lymphocytes, 14\%, eosinophils, 8.5\%; D-dimer, $12.09 \mu \mathrm{g} / \mathrm{mL}$; non-specific IgE, $174 \mathrm{IU} / \mathrm{mL}$; C3, $151 \mathrm{mg} / \mathrm{dL} ; \mathrm{C} 4,29.3 \mathrm{mg} / \mathrm{dL} ; \mathrm{CH} 50,50.4 \mathrm{U} / \mathrm{mL}$; urine protein, $30 \mathrm{mg} / \mathrm{dL}$; urine blood, negative. No abnormalities were found in liver and renal function or electrolytes. Herpes simplex virus, varicella zoster virus, measles, and rubella were postinfection patterns, and autoantibodies indicated negative data for autoimmune disease. The patient received an induced delivery for the full-term pregnancy and delivered safely the next day. After childbirth, the erythema immediately improved without treatment (Fig. 1c).

Serum were collected 7 days before and 7 days after delivery and stored at $-80^{\circ} \mathrm{C}$ before use. Two weeks after delivery, patch and prick tests were performed using her serums and the results were negative. The serum IgG levels against dominant bacteria and fungus on human skin were as follows: Staphylococcus aureus A, 9.76 and $13.8 \mathrm{mg} / \mathrm{L}$; S. aureus B, 26.6 and $40.9 \mathrm{mg} / \mathrm{L}$; enterotoxin TSST, 30.2 and $47.0 \mathrm{mg} / \mathrm{L}$; enterotoxin C, 9.35 and $16.0 \mathrm{mg} / \mathrm{L} ;$ Malassezia, 2.98 and $5.30 \mathrm{mg} / \mathrm{L}$; and Candida, 61.6 and $80.6 \mathrm{mg} / \mathrm{L}$, before and after delivery, respectively. We also measured cytokine concentration in the serum: IFN- $\gamma$, TNF- $\alpha$, TNF- $\beta$, IL-1 $\beta$, IL2, IL-4, IL-5, IL-6, IL-8, IL-9, IL-10, IL-12p70, IL-17A, IL-17F, IL-22, IL-33, GM-CSF, and TSLP by flow cytometric analyses using AimPlex (COSMO BIO Co., Ltd., Tokyo, Japan). Th2 cytokines including IL-33 were elevated before delivery. On the other hand, inflammatory markers such as IL-12, TNF- $\alpha$, and IFN- $\gamma$ were unchanged before and after delivery (Fig. 2).

\section{Discussion}

PUPPP is definite as a phenomenon of the skin eruption, which appeared at the end of the first pregnancy and diminished immediately after delivery [1]. In the current case, the target

\section{Karger'=}




\section{Case Reports in Dermatology}

Case Rep Dermatol 2021;13:18-22

DOI: $10.1159 / 000511494$

(c) 2021 The Author(s). Published by S. Karger AG, Basel www.karger.com/cde

Ishikawa-Nishimura et al.: Pruritic Urticarial Papules and Plaques of Pregnancy and Cytokine Profile

lesions on the extremities were initial phenotype. The target lesion may be triggered by viral or bacterial infection, drug eruption, or autoimmune disease [4, 5]. Because of the negative results for the infection, we speculated that some immune or allergic reaction associated with the pregnancy might induce the appearance of the rare phenomenon.

Initially, we speculated that the maternal blood during pregnancy contains some antigenic substances including fetal components, and we performed patch and prick tests using the patient's serum collected before and after delivery. The results were all negative. Secondly, various antibody titers against external factors, including skin-resident bacteria and fungus, were measured. As the result, all of the IgG antibody titers against $S$. aureus, enterotoxin, Malassezia, and Candida were higher in the serum after delivery compared to before delivery. The results indicated that the immune system against skin-resident bacteria and fungus would be enhanced when eruption appeared; one of the reasons is that the pathogen is able to invade easily into the eczematous abdominal skin extended during pregnancy. Lastly, various serum cytokine levels were measured before and after delivery. IL-8 concentration is increased in the end of pregnancy to contract the uterus. It is known that Th2 cytokines are superior compared to the Th1 system during pregnancy for the tolerance to the fetus [6]. In fact, Th2 cytokines, including IL-33 and IL-9, were increased in the current case, probably produced from ILC2 and Th2 cells, but severe eczematous and expanded lesions promoted the production of IL-33 from epithelial cells [7] and form the placenta during pregnancy. IL-9 is mainly produced from memory B cell and Th9 and promotes survival of a variety of mast cells, $B$ cells, T cells, and structural cells and the activation of intracellular targets. In normal pregnancy, IL-9 is usually undetectable or slightly increased [8], but IL-9 was elevated in the current case. IL-9 might enhance the Th2 immune reaction in PUPPP.

In conclusion, it will be easy to become eczematous and to allow some antigens to invade into the skin because of the abdominal hyperextension during pregnancy. The immune mechanism of upregulated Th2 cytokine profile, including IL-9 and IL-33, and the reaction against skin-resident bacteria and fungus might be involved in the pathogenesis of PUPPP.

\section{Statement of Ethics}

This research complies with the guidelines for human studies and includes evidence that the research was conducted ethically in accordance with the World Medical Association Declaration of Helsinki. The patient gave written informed consent to publish her case, including publication of images.

\section{Conflict of Interest Statement}

The authors declare that no competing interests exist.

\section{Funding Sources}

None of the authors received any financial support for the present study.

\section{Karger'}




\section{Case Reports in Dermatology}

\begin{tabular}{l|l}
\hline Case Rep Dermatol 2021;13:18-22 \\
\hline DOI: 10.1159/000511494 & $\begin{array}{l}\text { (c) 2021 The Author(s). Published by S. Karger AG, Basel } \\
\text { www.karger.com/cde }\end{array}$ \\
\hline
\end{tabular}

Ishikawa-Nishimura et al.: Pruritic Urticarial Papules and Plaques of Pregnancy and Cytokine Profile

\section{Author Contributions}

M. Ishikawa-Nishimura, M. Kondo, Y. Matsushima, K. Habe, and K. Yamanaka took care of the patient. M. Ishikawa-Nishimura, M. Kondo, and K. Yamanaka wrote the manuscript.

\section{References}

1 Lawley TJ, Hertz KC, Wade TR, Ackerman AB, Katz SI. Pruritic urticarial papules and plaques of pregnancy. JAMA. 1979 Apr;241(16):1696-9.

2 Holmes RC, Black MM. The specific dermatoses of pregnancy. J Am Acad Dermatol. 1983 Mar;8(3):405-12.

3 Aronson IK, Bond S, Fiedler VC, Vomvouras S, Gruber D, Ruiz C. Pruritic urticarial papules and plaques of pregnancy: clinical and immunopathologic observations in 57 patients. J Am Acad Dermatol. 1998 Dec;39(6): 933-9.

4 Lerch M, Mainetti C, Terziroli Beretta-Piccoli B, Harr T. Current Perspectives on Erythema Multiforme. Clin Rev Allergy Immunol. 2018 Feb;54(1):177-84.

5 Yachoui R, Cronin PM. Systemic lupus erythematosus associated with erythema multiforme-like lesions. Case Rep Rheumatol. 2013;2013:212145.

6 Tada Y. Pregnancy and skin. Vis Dermatol. 2018 Sep;17(10):916-9.

7 Matsumoto K. Group 2 innate lymphoid cells and allergic diseases. Arerugi. 2016 May;65(3):153-8.

8 Holtan SG, Chen Y, Kaimal R, Creedon DJ, Enninga EA, Nevala WK, et al. Growth modeling of the maternal cytokine milieu throughout normal pregnancy: macrophage-derived chemokine decreases as inflammation/ counterregulation increases. J Immunol Res. 2015;2015:952571. 


\section{Case Reports in Dermatology}

\begin{tabular}{l|l}
\hline Case Rep Dermatol 2021;13:18-22 \\
\hline DOI: 10.1159/000511494 & $\begin{array}{l}\text { (c) 2021 The Author(s). Published by S. Karger AG, Basel } \\
\text { www.karger.com/cde }\end{array}$ \\
\hline
\end{tabular}

Ishikawa-Nishimura et al.: Pruritic Urticarial Papules and Plaques of Pregnancy and Cytokine Profile
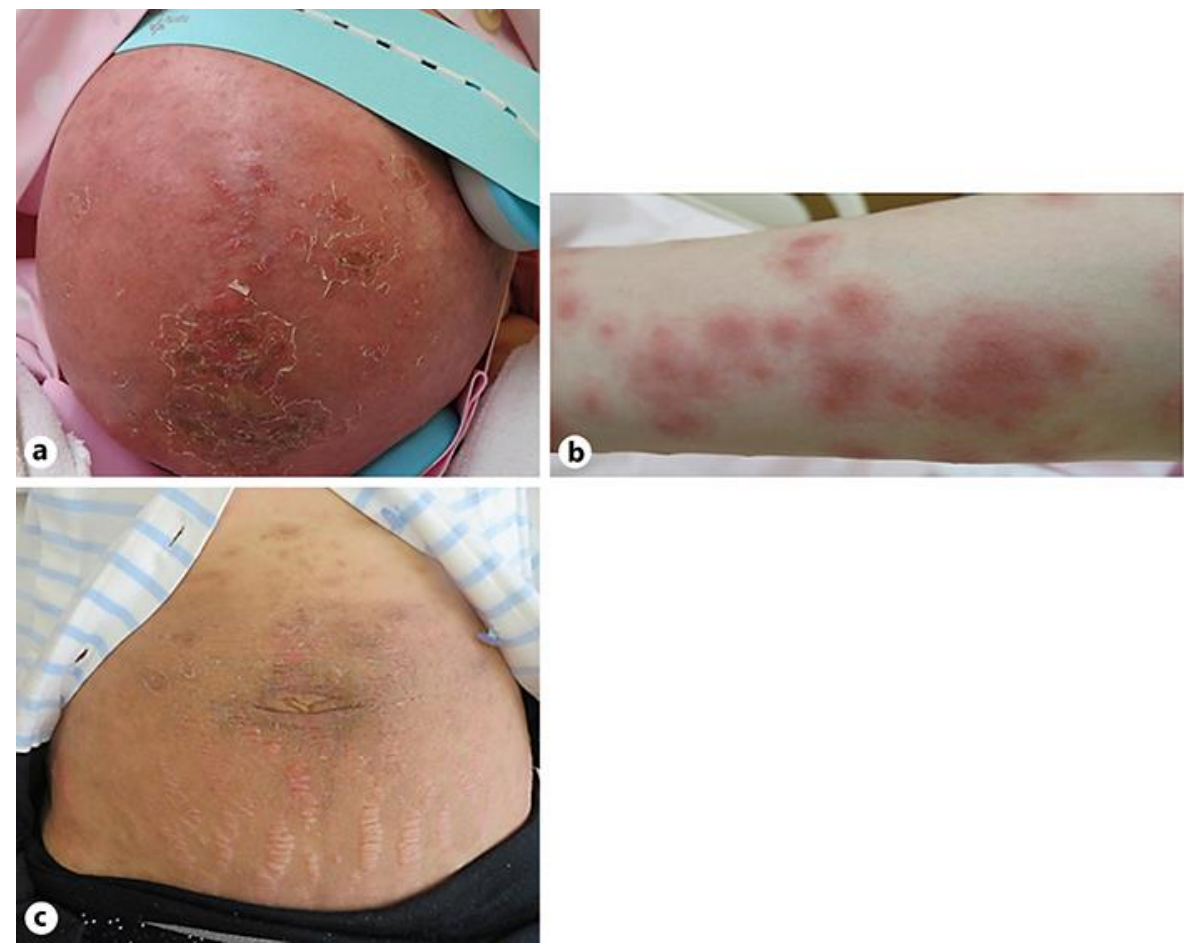

Fig. 1. a Irregular edematous erythema located on the abdominal stretch marks. $\mathbf{b}$ The target lesions scattered on the forearms. c The abdominal eruption immediately disappeared after delivery.

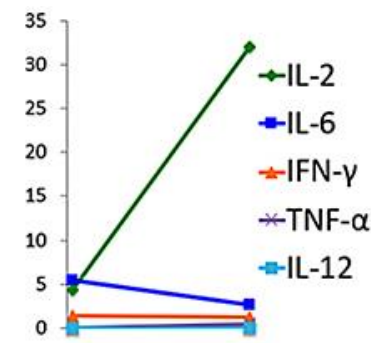

a $\quad$ Th1

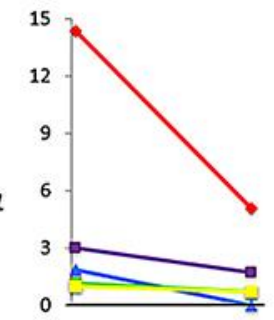

b

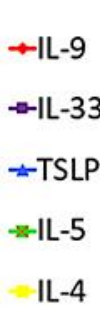

Th2

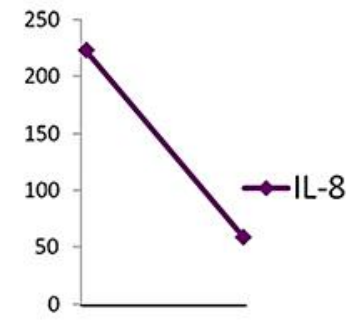

C

Fig. 2. a The elevation in Th1 cytokine before delivery. b The decrease in Th2 cytokine after delivery. c IL-8 levels before and after delivery. 